\title{
IMPACT OF ADDING BIOGAS LIQUID SLURRY ON SOIL SURFACE ON PENETRATION RESISTANCE
}

\author{
Mostfa K. El-Bakhshawan ${ }^{1}$, Mamdouh Minyawi $^{2}$ and \\ Abdulwahed M. Aboukarima ${ }^{1}$
}

\begin{abstract}
In this study, the impact of adding biogas liquid slurry (BLS) on soil surface on soil penetration resistance (soil cone index) was investigated. The soil penetration resistance was measured using two types of penetrometers: a hand-held type and a hammer type. The BLS application rates were 0, 2, 4 and $6 \mathrm{lit} / \mathrm{m}^{2}$. The BLS was spread on the soil surface three days before measurements. The soil penetration resistance was measured up to a $20 \mathrm{~cm}$ depth in no-till sandy clay loam soil. The statistical analysis showed that the effects of the BLS application on the soil penetration resistance were significantly different $(P<0.05)$. The highest penetration resistance value was found in the control application (no BLS applied) and the lowest value was obtained in the BLS application of $6 \mathrm{lit} / \mathrm{m}^{2}$. The average values of soil penetration resistance measured by the two types of penetrometers within the penetration depth profile of 0-20 cm for the control treatment were $3756 \mathrm{kPa}$ (hand-held type) and $3743 \mathrm{kPa}$ (hammer-type). The lower soil penetration resistances were measured as $2315 \mathrm{kPa}$ (hand-held type) and $2394 \mathrm{kPa}$ (hammertype) at a BLS application rate of $6 \mathrm{lit} / \mathrm{m}^{2}$. The results also showed that the soil penetration resistance was affected by BLS application rate and the penetration depth, and this effect can be predicted using the models generated from the study (within the investigated range of the variables). It could be concluded that adding BLS to the soil surface reduced soil penetration resistance, which may improve root growth and distribution. In addition, the study concluded that the effects of BLS application on soil properties and soil strength over longer periods should be further studied. Keywords: Biogas, liquid, slurry, soil, penetration, resistance.
\end{abstract}

\footnotetext{
${ }^{1}$ Senior Researcher, Agricultural Engineering Research Institute, Agricultural Research Centre, Egypt.

${ }^{2}$ Researcher, Agricultural Engineering Research Institute, Agricultural Research Centre, Egypt.
} 


\section{INTRODUCTION}

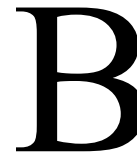

iogas technology has received a great deal of attention in Egypt, and different biogas projects have been initiated in villages in rural areas across the country. Biogas liquid slurry (BLS) is an anaerobic digested organic material released as byproduct from the biogas production (Islam, 2006). Improper utilization of BLS leads to environmental pollution; therefore, BLS must be properly utilized to ensure biogas projects are viewed as environmentally friendly. The impact of biogas slurry application on soil clarified positive trend on the content of organic matter, the bulk density and the porosity, besides, biogas slurry in combination of mineral fertilizers (1:1) could be used as soil amendments for obtaining short-term and long-term benefits in terms of production increments and soil amelioration (Malav et al., 2015).

Soil strength has been regarded as an important characteristic that affects many aspects of agricultural soils, such as the performance of cultivation implements, root growth, least-limiting water range, and trafficabilty (Vanags et al., 2004). The threshold level at which soil strength hinders root elongation varies depending on the plant species, but it usually ranges from 2000-3000 kPa (Atwell, 1993). Letey (1995) reported a lower threshold value of $1800 \mathrm{kPa}$.

Understanding the physical properties of soil that are changed by the application of BLS is essential to formulate best management practices for crop production. Several studies have reported on the impact of manure application on soil strength, which influences root growth and distribution. However, one of the common applications for decreasing soil compaction is the addition of organic material (Mujdeci, 2011). Kanto et al. (2012) reported that swine manure extract reduced soil strength when it was applied.

By browsing literature, it is concluded that the addition of biogas slurry to the soil has potential to improve the growth and yield of crops. On the other hand, the effects of BLS on soil penetration resistance should be elucidated. Thus, the main objective of the current study is to characterize the change in soil penetration resistance of sandy clay loam soil after receiving different amounts of BLS on the soil surface over a short application period. The results will assist the understanding of the effects 
of BLS as an organic fertilizer on changes to soil penetration resistance. This could help to select the best conditions for agricultural practices.

\section{MATERIALS AND METHODS}

\section{Soil and Site Description}

The experiments were carried out on soil surface located at Tractors and Farm Machinery Testing \& Research Station (Sabahia, Alexandria Governorate, Egypt). The soil was sandy clay loam texture. No tillage practices were conducted in the experimental site. The undisturbed surfaces $(0-30 \mathrm{~cm})$ of soil samples were collected to determine several characteristics, as shown in Table (1). The particle size distribution of the soil samples was determined in the laboratories of the services unit of soil analysis, Soil Department, Faculty of Agriculture, Alexandria University. In order to determine the soil moisture content, undisturbed soil samples were taken using a steel cylinder of $100 \mathrm{~cm}^{3}$ volume from each plot before spreading biogas liquid slurry on the soil surface at depths of $0-15$ and $15-30 \mathrm{~cm}$. Soil moisture content was calculated from the weight difference between wet and oven dry samples $\left(72 \mathrm{~h}\right.$ at $\left.105^{\circ} \mathrm{C}\right)$. The average soil bulk density and soil moisture content are listed in Table (1).

Table (1). Characteristics of the investigated soil.

\begin{tabular}{|l|c|c|}
\hline \multicolumn{1}{|c|}{ Variable } & Unit & Value \\
\hline Sand & $(\%)$ & 51 \\
\hline Silt & $(\%)$ & 20 \\
\hline Clay & $(\%)$ & 29 \\
\hline Soil texture & $(---)$ & Sandy clay loam \\
\hline Organic matter & $(\%)$ & 2.13 \\
\hline Average bulk density & $\left(\mathrm{g} / \mathrm{cm}^{3}\right)$ & 1.36 \\
\hline Average soil moisture content & $(\%, \mathrm{db})$ & 10.68 \\
\hline
\end{tabular}

\section{Biogas liquid slurry (BLS) treatments}

The BLS used in this work was produced from the biogas digester of the project "Development of Biogas Production and Utilization Systems" which financially supported by the Agricultural Development Program (ADP), Agricultural Research Center. This project was located at Tractors and Farm machinery Testing \& Research Station, Alexandria, Egypt. Table (2) shows the characteristics of the investigated BLS. However, the 
BLS was collected from a precipitation pan. The justification for the choice of the particular liquid slurry was because it was available in huge quantities and there was no local study indicating impact of incorporation of the BLS on soil surface on soil penetration resistance. The components of the BLS were analyzed in the laboratories of the services unit of soil analysis, Soil Department, Faculty of Agriculture, Alexandria University. The collected BLS was spread on the soil surface with different application rates. The BLS application rates were 2, 4, and $6 \mathrm{lit} / \mathrm{m}^{2}$ and based on the density of BLS, the application rates were about 25, 50 and $75 \mathrm{Mg} / \mathrm{ha}$. The plot area was $1 \times 1 \mathrm{~m}$. In addition, a control treatment condition was considered, i.e. no BLS was spread on the soil surface. A completely randomized block design with three replicates was applied. Figure (1) depicts a pictorial of the covered soil surface with different BLS treatments.

Table (2). Characteristics of the investigated BLS.

\begin{tabular}{|l|c|c|}
\hline Variable & Unit & Value \\
\hline $\mathrm{N}$ & $\%$ & 0.84 \\
\hline $\mathrm{P}$ & $\%$ & 0.34 \\
\hline $\mathrm{K}$ & $\%$ & 1.61 \\
\hline Density & $\mathrm{g} / \mathrm{ml}$ & 1.255 \\
\hline Total Solid & $\%$ & 5.0 \\
\hline
\end{tabular}

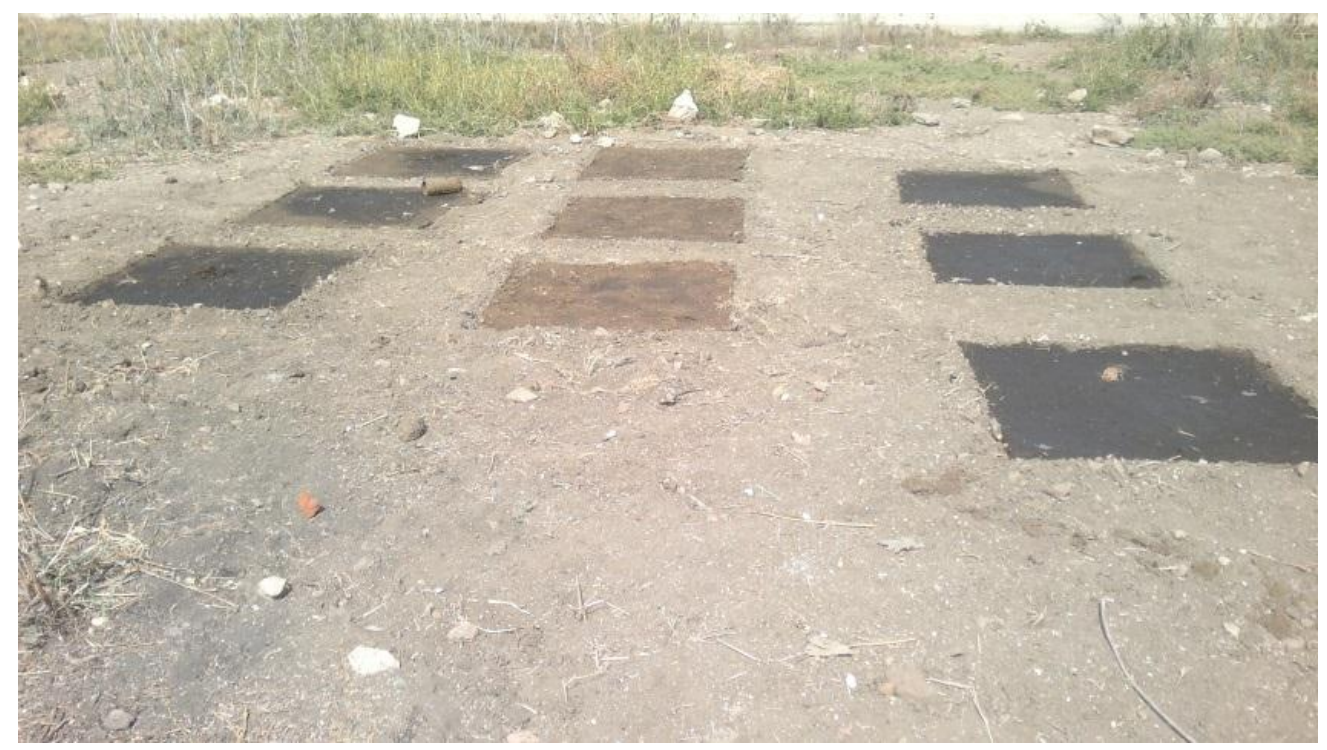

Figure (1). Pictorial of the covered soil surface with different BLS treatments. 


\section{Soil Penetration Resistance Measurements}

Two cone penetrometers were used in this study. One was the handoperated soil cone penetrometer shown in Figure (2). It had a cone with a base area of $1.30 \mathrm{~cm}^{2}$ and graduated driving shaft and the penetration values was monitored on direct readout in pressure units. Soil penetration resistance readings were recorded at $2.54 \mathrm{~cm}$ intervals. It was used to determine soil penetration resistance up to a depth of $20 \mathrm{~cm}$. The penetrometer was pushed into the soil by hand at a speed of approximately $0.30 \mathrm{~mm} / \mathrm{s}$ (ASAE, 2000). Measurements of penetration resistance were made at three random locations over the plot area. The second method for determining soil penetration resistance was accomplished by using a dynamic cone penetrometer, shown in Figure (3). The procedure for using such a device was described by Herrick and Jones (2002). The dynamic cone penetrometer calculates soil resistance from the work done to raise a hammer (mass M) lifted to a height, $h$, above an anvil. Before the mass is dropped on the anvil, the penetrometer is assumed to be at equilibrium with the indented soil surface. When the hammer hits the anvil, the hammers mass (M) and the shaft mass (m) move together into the soil. The energy applied by the action of dropping the hammer against the force of gravity is described in equation 1:

$$
F=M \times g \times h
$$

where $\mathrm{F}$ is the energy $(\mathrm{J})$, and $\mathrm{g}$ is the gravity-acceleration constant $(9.81$ $\mathrm{m} / \mathrm{s}^{2}$ ). By assuming that all the energy loss is absorbed by the shaft, there is negligible friction between the penetrometer and the soil. From the basal area of the cone and the distance of penetration, the penetration resistance (PR) is obtained using equation 2 :

$$
P R=\frac{F}{A \times L} \times\left[\frac{M}{(M+m)}\right]
$$

where $\mathrm{PR}$ is the resistance to penetration $(\mathrm{Pa}), \mathrm{L}$ is the penetration distance $(\mathrm{m})$, and $\mathrm{A}$ is the basal area of the cone $\left(\mathrm{m}^{2}\right)$.

\section{Statistical Analysis}

Analysis of variance (ANOVA) was applied to assess the effects of BLS application rate and penetration depth treatments on soil penetration resistance. Following the ANOVA test, the LSD test was performed to compare differences in means of the soil penetration resistance at 
significance level of $\mathrm{P} \leq 0.05$. The statistical analyses were performed using SAS software (SAS, 1998). In addition, an Excel spreadsheet was utilized to examine the differences between soil penetration resistance measured by the hand-held penetrometer and the hammer penetrometer.

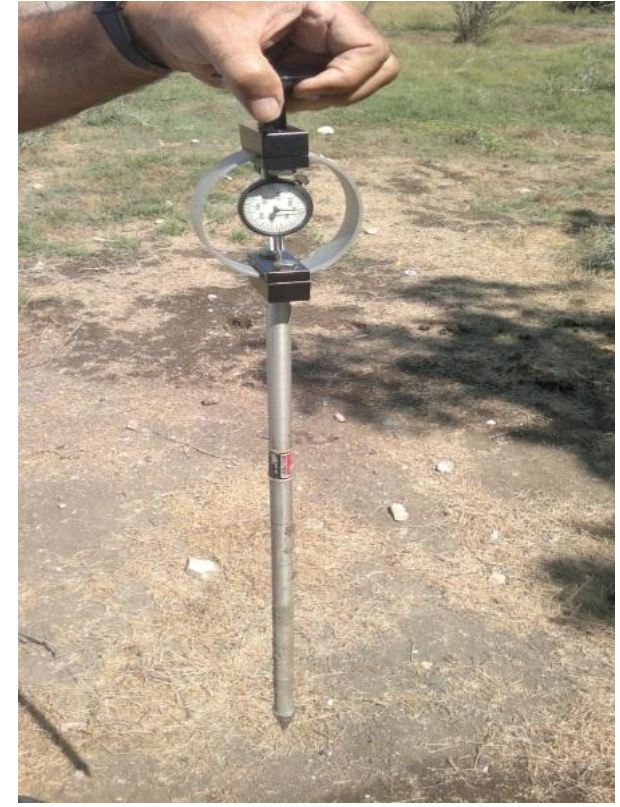

Figure (2). Hand-held penetrometer.

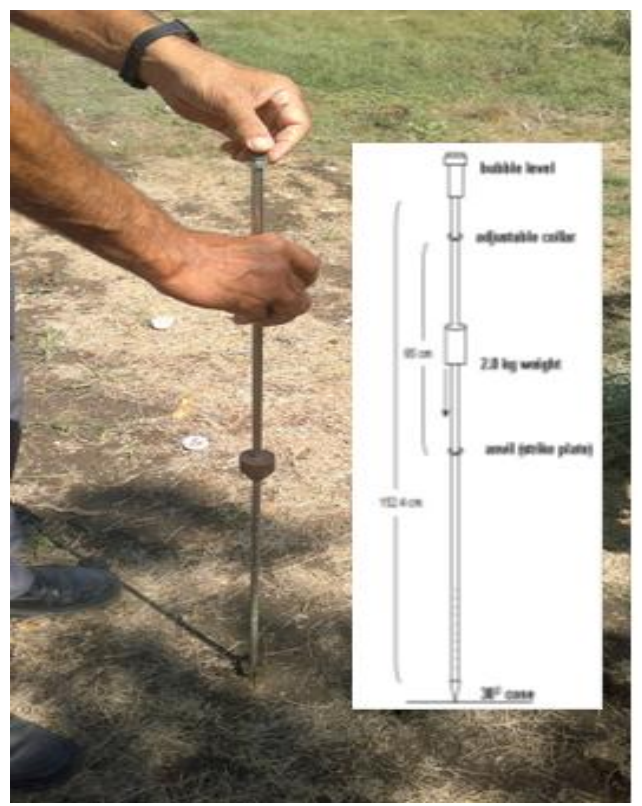

Figure (3). Hammer penetrometer

\section{RESULTS AND DISCUSSION}

\section{Soil penetration resistance data analysis}

The scatter plots with linear regression line between penetration depth and soil penetration resistance as measured by hand-held penetrometer and hammer penetrometer after the spread of BLS on soil surface at different rates are shown in Figure (4) and Figure (5), respectively. Generally, soil penetration resistance had a general tendency to increase with penetration depth, which agrees with the findings of Cavalaris and Gemtos (2002) who reported the same relationship for no-till soil. The slope of regression line indicates the steepness of a line and the intercept indicates the location where it intersects an axis. The slope and the intercept define the linear relationship between two variables, and can be used to estimate an average rate of change. However, the rate of change of soil penetration resistance relative to penetration depth could be explained by the slope of the line. 


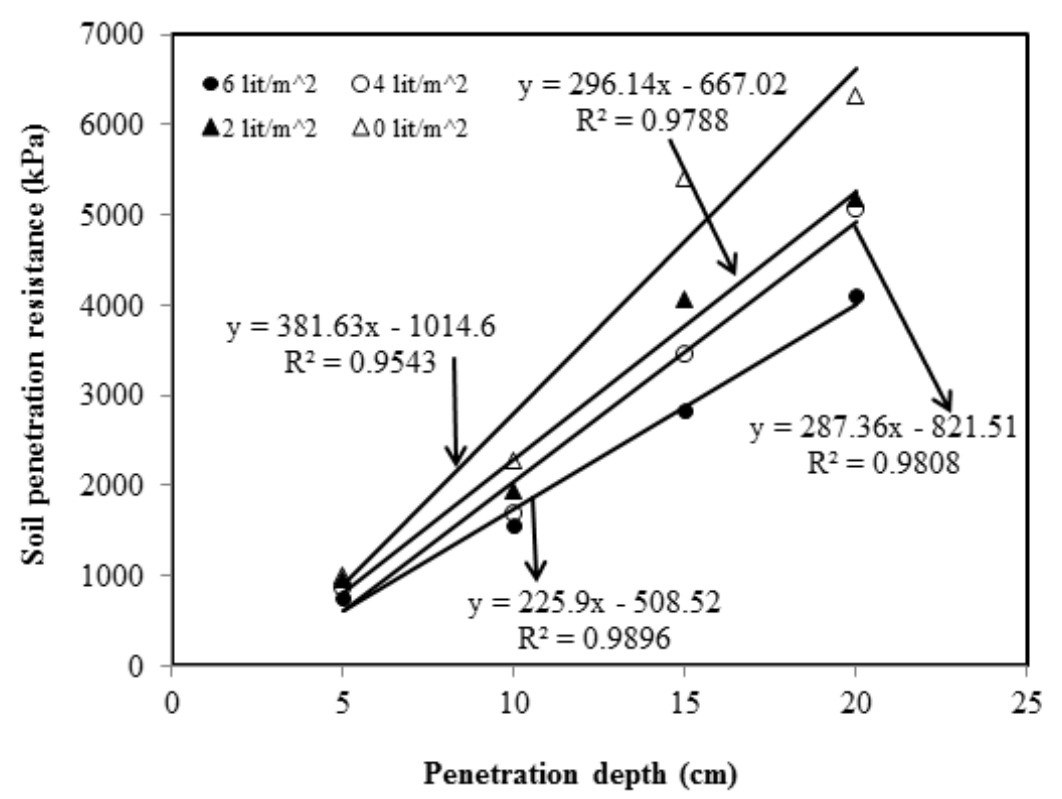

Figure (4). Scatter plot with linear regression line between penetration depth and soil penetration resistance as measured by hand-held penetrometers after the spread of BLS on soil surface at different rates.

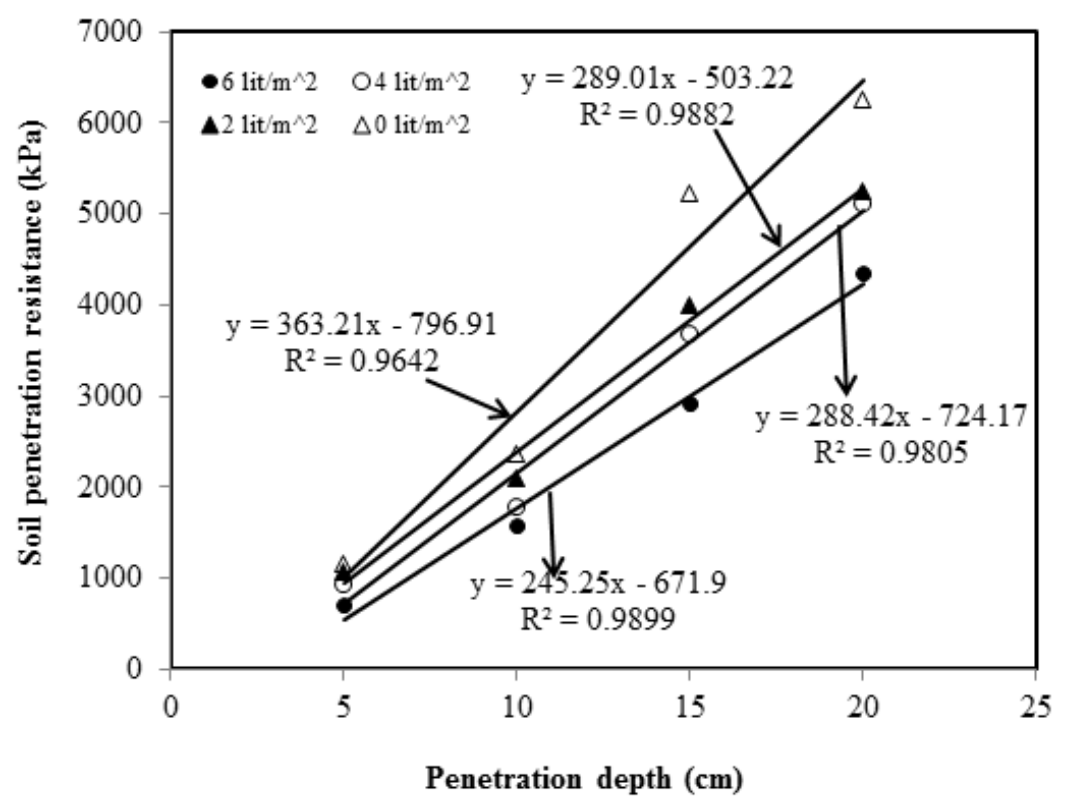

Figure (5). Scatter plot with linear regression line between penetration depth and soil penetration resistance as measured by hammer penetrometers after the spread of BLS on soil surface at different rates. 
From Figure (4), the slopes of regression line were 225.9, 287.36, 296.41 and $381.63 \mathrm{kPa} / \mathrm{cm}$ when BLS spread on soil surface with application rates of $6,4,2$ and $0 \mathrm{lit} / \mathrm{m}^{2}$, respectively. This implies that the linear trend line was steeper for soil penetration resistance at BLS application rate of $0 \mathrm{lit} / \mathrm{m}^{2}$ compared to other application rates of 6,4 and $2 \mathrm{lit} / \mathrm{m}^{2}$. This result also implies that the soil penetration resistance of no-till soil increased more rapidly up to penetration depth $(0-20 \mathrm{~cm})$ and the same findings was observed by Kumar et al. (2012). The same trend was also observed for soil penetration resistance which was measured by hammer penetrometer as shown in Figure (5). The slopes of regression line were $245.25,288.42,289.01$ and $363.21 \mathrm{kPa} / \mathrm{cm}$ when BLS spread on soil surface with application rates of $6,4,2$ and $0 \mathrm{lit} / \mathrm{m}^{2}$, respectively. The observed reduction in soil penetration resistance when increasing BLS rate was a result of the improvement in soil structure by incorporating organic manure, as reported by Thomas et al. (1996). The finding that BLS decreased soil penetration resistance is in agreement with Khaleel $\boldsymbol{e t}$ al. (1981) and Haynes and Naidu (1998), who observed that increases in soil cone index as a result of waste applications can reduce bulk density (Jokela et al., 2009).

The data showing the regression models in Figures (4) and (5) reflect the relationship between the penetration depth and soil penetration resistance for each application rate. In the regression equation, $y$ represents penetration resistance $(\mathrm{kPa})$ and $\mathrm{x}$ refers to the penetration depth $(\mathrm{cm})$. The coefficient of determination $\left(\mathrm{R}^{2}\right)$ fell in the range of $0.9543-0.9896$ as shown in Figure (4) when using the hand-held penetrometer to measure soil penetration resistance. When using the hammer penetrometer to measure soil penetration resistance, the coefficient of determination $\left(\mathrm{R}^{2}\right)$ fell in the range of 0.9642-0.9899 as shown in Figure (5). This implies strong correlation between penetration depth and soil penetration resistance.

The average of two soil penetration resistance measurements within the penetration depth profile from $0-20 \mathrm{~cm}$ is shown in Figure (6) for different BLS application rates. It is clear that the control treatment had higher penetration resistance when the hand-held penetrometer and hammer penetrometer were utilized: $3756 \mathrm{kPa}$ and $3743 \mathrm{kPa}$, respectively. The lower penetration resistance was obtained at the application rate of 6 $1 \mathrm{it} / \mathrm{m}^{2}$ when the hand-held penetrometer and hammer penetrometer were 
utilized: $2315 \mathrm{kPa}$ and $2394 \mathrm{kPa}$, respectively. However, the threshold level at which soil strength hinders root elongation varies with plant species, but usually falls in the range of 2000-3000 kPa (Atwell, 1993). In addition, the relationship between overall average soil penetration resistances measured by the two penetrometers is shown in Figure (7) with an $\mathrm{R}^{2}$ value of 0.9971 .

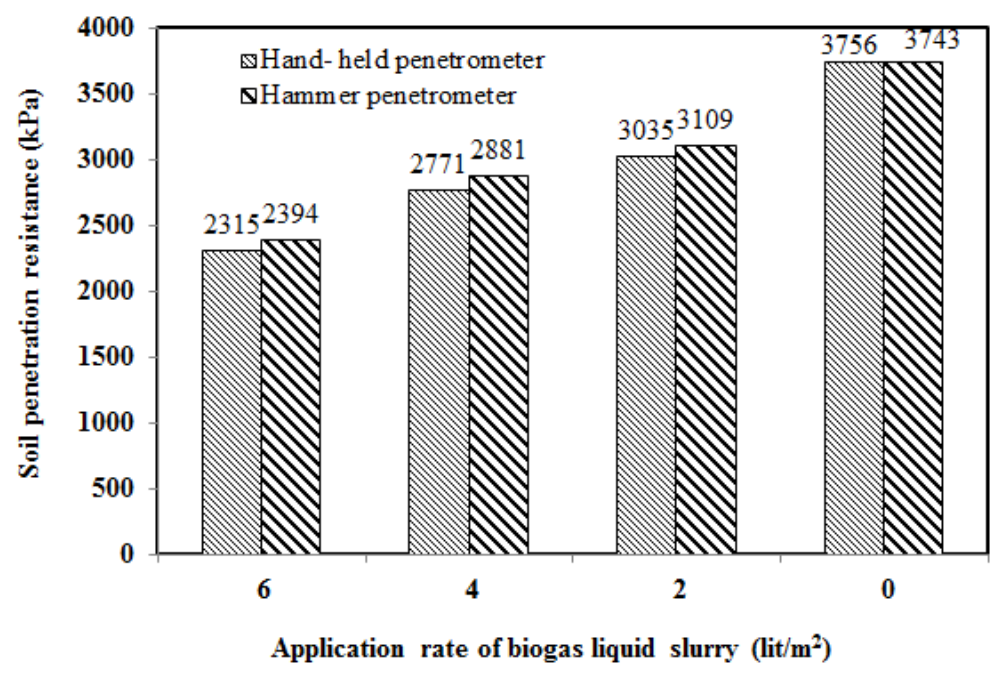

Figure (6). Average of the soil penetration resistance values measured by two penetrometers within the penetration depth profile from $0-20 \mathrm{~cm}$ for different BLS application rates.

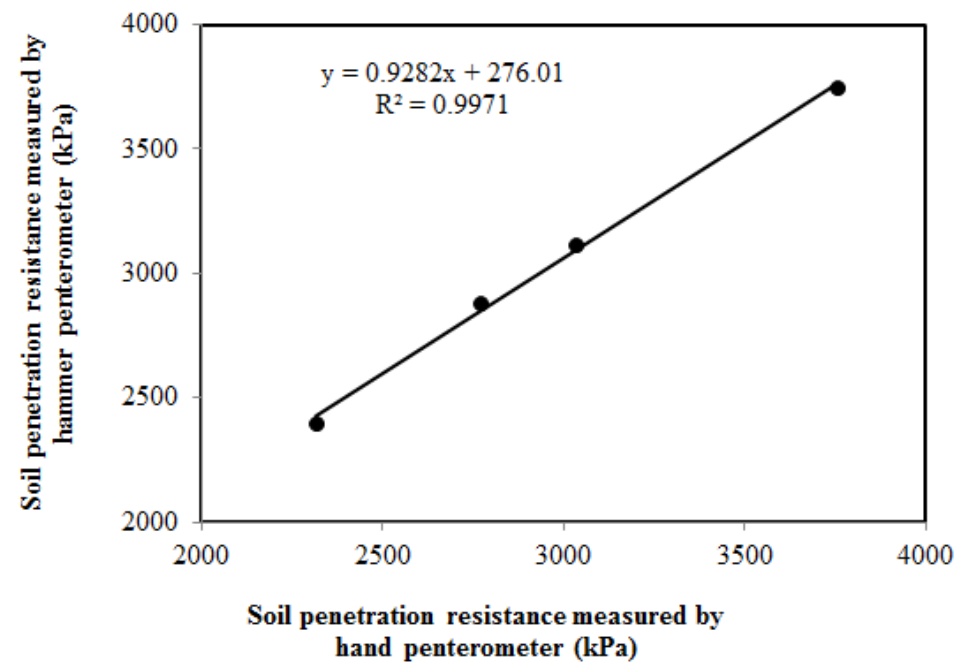

Figure (7). Relationship between overall average soil penetration resistance measured by two penetrometers. 
Because $\mathrm{R}^{2}$ indicates the amount of total variability explained by the regression model, $99.71 \%$ of the total variation in the soil penetration resistance can be explained by the linear relationship between the two methods of measuring soil penetration resistances. The other $0.29 \%$ of the total variation in the soil penetration resistance measured by hammer penetrometer remains unexplained.

\section{Statistical Analysis}

Analysis of variance (ANOVA) for soil penetration resistance as affected by penetration depth and BLS application is shown in Table (3). Penetration depth and BLS application had significant $(\mathrm{P}<0.01)$ effects on soil penetration resistance. Penetration depth and BLS application rate interaction effects on the soil penetration resistance was found statistically significant $(\mathrm{P}<0.01)$.

Table (3). Analysis of variance (ANOVA) for soil penetration resistance.

\begin{tabular}{|c|c|c|c|}
\hline \multirow[t]{3}{*}{ Source of variation } & \multirow[t]{3}{*}{$\mathrm{DF}^{[\mathrm{a}]}$} & \multicolumn{2}{|c|}{$\operatorname{Pr}>F$} \\
\hline & & \multicolumn{2}{|c|}{ Soil penetration resistance measured by: } \\
\hline & & $\begin{array}{c}\text { Hand-held } \\
\text { penetrometer }\end{array}$ & $\begin{array}{c}\text { Hammer } \\
\text { penetrometer }\end{array}$ \\
\hline Replicates & 2 & 0.095 & 0.925 \\
\hline $\begin{array}{l}\text { Application rate of } \\
\text { BLS (AR) }\end{array}$ & 3 & 0.0000 & 0.0000 \\
\hline $\begin{array}{l}\text { Penetration depth } \\
\text { (PD) }\end{array}$ & 3 & 0.0000 & 0.0000 \\
\hline $\mathrm{AR} \times \mathrm{PD}$ & 9 & 0.0000 & 0.0000 \\
\hline
\end{tabular}

\footnotetext{
${ }^{\text {[a] }}$ Degree of freedom.
}

The mean values of soil penetration resistance measured by the hand-held penetrometer (Table 4) were 3755.8, 3034.8, 2770.5 and $2315.3 \mathrm{kPa}$ for BLS application rates of $0,2,4$ and $6 \mathrm{lit} / \mathrm{m}^{2}$, respectively. The percent reduction in soil penetration resistance was approximately $17 \%$ when BLS was applied to the soil surface at a rate of $2 \mathrm{lit} / \mathrm{m}^{2}$, when compared to the zero BLS condition. The reduction percentage was approximately $23 \%$ and $36 \%$ when BLS was applied to the soil surface at the rates of 4 $\mathrm{lit} / \mathrm{m}^{2}$ and $6 \mathrm{lit} / \mathrm{m}^{2}$, respectively, compared to zero BLS.

The mean values of soil penetration resistance measured by the hammer penetrometer (Table 4) were 3743.2, 3109.4, 2881.1 and $2393.8 \mathrm{kPa}$ for BLS application rate of $0,2,4$ and $6 \mathrm{lit} / \mathrm{m}^{2}$, respectively. The percent 
reduction in the soil penetration resistance was approximately $19 \%$ when BLS was applied to the soil surface at the rate of $2 \mathrm{lit} / \mathrm{m}^{2}$, compared to zero BLS. Finally, the reduction percentage was approximately $26 \%$ and $38 \%$ when BLS was applied to the soil surface at a rate of $4 \mathrm{lit} / \mathrm{m}^{2}$ and 6 $\mathrm{lit} / \mathrm{m}^{2}$, respectively, compared to zero BLS.

Table (4). Mean* soil penetration resistance as affected by application rate of BLS and penetration depth.

\begin{tabular}{|c|c|c|}
\hline \multirow{2}{*}{$\begin{array}{l}\text { Application rate of BLS } \\
\qquad\left(\mathrm{lit} / \mathrm{m}^{2}\right)\end{array}$} & \multicolumn{2}{|c|}{ Soil penetration resistance measured by: } \\
\hline & $\begin{array}{c}\text { Hand-held } \\
\text { penetrometer }(\mathrm{kPa})\end{array}$ & $\begin{array}{c}\text { Hammer } \\
\text { penetrometer }(\mathrm{kPa})\end{array}$ \\
\hline 0 & $3755.8 \mathrm{a}$ & $3743.2 \mathrm{a}$ \\
\hline 2 & $3034.8 b$ & $3109.4 b$ \\
\hline 4 & $2770.5 b$ & $2881.1 \mathrm{~b}$ \\
\hline 6 & $2315.3 \mathrm{c}$ & $2393.8 \mathrm{c}$ \\
\hline $\operatorname{LSD}^{[\mathrm{aa}]}(5 \%)$ & 213.9 & 233.1 \\
\hline \multicolumn{3}{|l|}{ Penetration depth $(\mathrm{cm})$} \\
\hline $0-5$ & $898.8 \mathrm{~d}$ & $968.6 \mathrm{~d}$ \\
\hline $5-10$ & $1867.2 \mathrm{c}$ & $1958.0 \mathrm{c}$ \\
\hline $10-15$ & $3939.8 b$ & $3957.6 b$ \\
\hline $15-20$ & $5170.6 \mathrm{a}$ & $5243.3 \mathrm{a}$ \\
\hline LSD (5\%) & 213.9 & 233.1 \\
\hline
\end{tabular}

${ }^{[*]}$ Means followed by different letters in each column are significantly different at $\mathbf{P}=\mathbf{0 . 0 5}$.

${ }^{[\mathrm{a}]}$ LSD $=$ Least significant difference.

The mean average soil penetration resistance values in the $0-5,5-10,10-$ 15 , and 15-20 cm penetration depths for the control case and the cases with application rates of 6,4 , and $2 \mathrm{lit} / \mathrm{m}^{2}$, are shown in Table (4). In the 5-10 $\mathrm{cm}$ penetration depth, the soil penetration resistance values were measured at $1867.2 \mathrm{kPa}$ and $1958.0 \mathrm{kPa}$ when using the hand-held and hammer penetrometers, respectively. However, Reichert et al. (2004) reported that the penetration resistance for a $6-10 \mathrm{~cm}$ soil layer was greater than that in $2000 \mathrm{kPa}$ for no-tillage soil. In the $15-20 \mathrm{~cm}$ penetration depth, the soil penetration resistance values were measured at $3939.8 \mathrm{kPa}$ and $3957.6 \mathrm{kPa}$ by the hand-held and hammer penetrometers, respectively. The higher penetration resistance values in the $10-20 \mathrm{~cm}$ penetration depth might be related to the weight of the surface soil and physicochemical property differences (Becerra et al., 2010). It could be 
concluded that additives of BLS to soil surface reduced soil penetration resistance, which may improve root growth and distribution. In addition, the study concluded that the effects of BLS application on the soil properties and on soil strength over longer periods should be further studied.

To test the hypothesis that says the mean of soil penetration resistances measured by the two penetrometers is the same for all treatments; an analysis of variance (ANOVA) using Excel spreadsheet was obtained and is shown in Table (5). Columns represent the two soil penetration resistances and rows represent the values of soil penetration resistances corresponding to penetration depth for different treatments. The P-value of 0.062 is for a test of the hypothesis as shown in Table (5) for columns. Because P-value is high than 0.05, thus the hypothesis of there was no difference between two soil penetration resistances was accepted.

Table (5). Analysis of variance (ANOVA) obtained by Excel spreadsheet.

\begin{tabular}{|c|c|c|c|c|c|c|}
\hline $\begin{array}{c}\text { Source of } \\
\text { Variation }\end{array}$ & DF & Sum Square & $\begin{array}{c}\text { Mean } \\
\text { square }\end{array}$ & F & P-value & $\begin{array}{c}\mathrm{F} \\
\text { critical }\end{array}$ \\
\hline Rows & 47 & $3.07 \mathrm{E}+08$ & 6535980 & 253.8 & $2.12 \mathrm{E}-44$ & 1.62 \\
\hline Columns & 1 & 94597.54 & 94597 & 3.67 & 0.062 & 4.05 \\
\hline Error & 47 & 1210202 & 25749 & & & \\
\hline Total & 95 & $3.08 \mathrm{E}+08$ & & & & \\
\hline
\end{tabular}

\section{Regression Analysis}

To formulate the relationship between penetration depth and BLS application rate, multiple linear regressions were performed with the Excel spreadsheet. The results showed that soil penetration resistance is affected by BLS application rate and penetration depth, and it can be predicted using the models generated from the study with the investigated range of the variables. The regression model for soil penetration resistance measured by the hand-held penetrometer and hammer penetrometer were showed in equations 3 and 4 respectively.

$$
\begin{gathered}
P R=-65.025+297.76 \times P D-458.595 \times A R \\
R^{2}=0.927 \quad S E=506.05 \quad \text { observations }=48 \\
P R=-32.55+296.47 \times P D-472.67 \times A R \\
R^{2}=0.944 \quad S E=433.28 \quad \text { observations }=48
\end{gathered}
$$

where $\mathrm{PR}$ is soil penetration resistance $(\mathrm{kPa}), \mathrm{PD}$ is penetration depth 
(cm), AR is the application rate of BLS $\left(1 \mathrm{it} / \mathrm{m}^{2}\right)$, and SE is the standard error $(\mathrm{kPa})$. As shown in Eq. (3) and Eq. (4), there was a negative correlation between soil penetration resistance and biogas liquid slurry application rate. However, a positive correlation was observed between soil penetration resistance and penetration depth.

\section{CONCLUSION}

The direct, short-term application of biogas liquid slurry on the soil surface in no-till sandy clay loam soil decreased soil penetration resistance. The reduction in soil penetration resistance measured by two penetrometers was affected by adding biogas liquid slurry on soil surface and penetration depth. The percent reduction in soil penetration resistance measured by the hand-held penetrometer was approximately $17 \%$ when biogas liquid slurry was applied at a rate of $2 \mathrm{lit} / \mathrm{m}^{2}$ compared to zero biogas liquid slurry. The reduction percentage was approximately $23 \%$ and $36 \%$ when the biogas liquid slurry was applied at the rates of $4 \mathrm{lit} / \mathrm{m}^{2}$ and $6 \mathrm{lit} / \mathrm{m}^{2}$ compared to zero biogas liquid slurry, respectively. Soil penetration resistance measured by two penetrometers was modeled by regression analysis. The independent variables were penetration depth and application rate of biogas liquid slurry. The coefficient of determination $\mathrm{R}^{2}$ was 0.927 for soil penetration resistance measured by hand-held penetrometer. Meanwhile it was 0.944 for soil penetration resistance measured by hammer penetrometer. There was a negative correlation between soil penetration resistance and biogas liquid slurry application rate. However, a positive correlation was observed between soil penetration resistance and penetration depth. The study recommended that the effects of biogas liquid slurry application on soil properties and soil strength over longer periods should be further studied.

\section{REFERENCES}

ASAE Standards. (2000). EP542 Feb99. Procedures for using and reporting data obtained with the soil cone penetrometer. St. Joseph, MI: ASAE.

Atwell, B.J. (1993). Response of roots mechanical impedance. Environ. Exp., Bot. 33:27-40. 
Becerra, A. T., G. F. Botta, X. L. Bravo, M. Tourn, F. B. Melcon, J.Vazquez, D. Rivero, P. Linares and G. Nardon (2010). Soil compaction distribution under tractor traffic in almond (Prunus amygdalus L.) orchard in Almería, Spain. Soil and Tillage Research, 107:49-56.

Cavalaris, C.K. and T.A. Gemtos (2002). Evaluation of four conservation tillage methods in the Sugar Beet Crop. Agricultural Engineering International: the CIGR Journal of Scientific Research and Development IV (June): pp 24.

Haynes, R.J. and R. Naidu (1998). Influence of lime, fertilizer and manure applications on soil organic matter content and soil physical condition: A review. Nutr. Cycl. Agroecosys., 51:123-137.

Herrick, J.E. and T.L. Jones (2002). A dynamic cone penetrometer for measuring soil penetration resistance. Soil Science Society of America Journal, 66:1320-1324.

Islam, M. S. (2006). Use of Bioslurry as organic fertilizer in Bangladesh International Workshop on the Use of Bioslurry Domestic Biogas Programmes 27-28 September 2006 Bangkok, Thailand,18p.

Jokela, W.E., J.H. Grabber, D.L. Karlen, T.C. Balser and D.E. Palmquist (2009). Cover crop and liquid manure effects on soil quality indicators in a corn silage system. Agron. J., 101:727-737.

Kanto, U., K. Jutamanee, Y. Osotsapar, S. Jattupornpong and C. Kaewprasit (2012). Effects of swine manure extract by foliar application and soil drenching on soil chemical properties and variable soil strength of cassava planted soils. Kasetsart J. Nat. Sci., 46:24-32.

Khaleel, R., K.R. Reddy and M.R. Overcash (1981). Changes in soil physical properties due to organic waste applications: A review. $J$. Environ. Qual., 10:133-141.

Kumar, A., Y. Chen, A. Sadek and S. Rahman (2012). Soil cone index in relation to soil texture, moisture content, and bulk density for notillage and conventional tillage. Agricultural Engineering International: CIGR Journal, 14(1), p16.

Letey, J. (1995). Relationship between soil physical properties and crop production. Adv. Soil Sci., 1:227-294. 
Malav, L.C., S. A. Khan and N. Gupta (2015). Impacts of biogas slurry application on soil environment, yield and nutritional quality of baby corn. VEGETOS, 28 (3):74-83.

Mujdeci, M. (2011). The effects of organic material applications on soil penetration resistance. Journal of Food, Agriculture \& Environment, 9 (3\&4):1045-1047.

Reichert, J.M., V.R. da Silva and D.J. Reinert (2004). Soil moisture, penetration resistance, and least limiting water range for three soil management systems and black beans yield. Conserving Soil and Water for Society: Sharing Solutions ISCO 2004 - 13th International Soil Conservation Organization Conference - Brisbane, Australia.

SAS (1998). User's guide, statistical analysis system. SAS Ins., Inc., SAS Circle, P.O.Box 8000, Cary, N.C.

Thomas, G.W., G.R. Haszler and R.L. Blevines (1996). The effects of organic matter and tillage on maximum compactibility of soils using the proctor test. Soil Sci., 161:502-508.

Vanags, C., B. Minasny and A. B. McBratney (2004). The dynamic penetrometer for assessment of soil mechanical resistance. $3^{\text {rd }}$ Australian New Zealand Soils Conference, 5-9 December 2004, University of Sydney, Australia.

$$
\text { الملخص العربي }
$$

تأثير إضافة سماد البيوجاز السائل على سطح التربة على مقاومة الاختراق

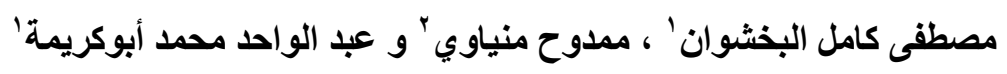

في هذه الدر اسة، تم تقييم تأثير إضاقة سماد البيوجاز السائل على سطح التربة لمدة قصيرة (بأيام أيام

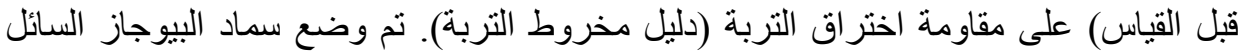

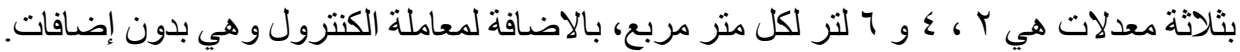

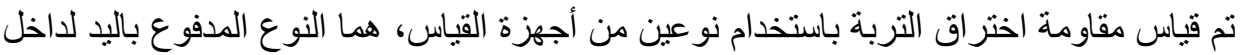

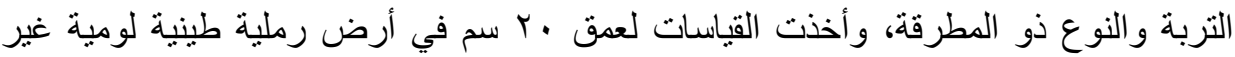

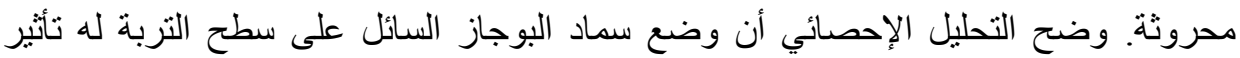

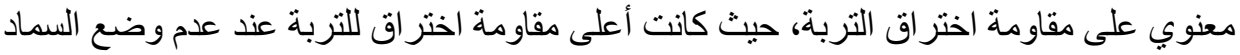

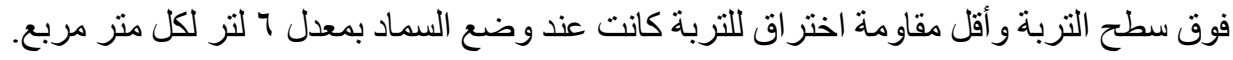

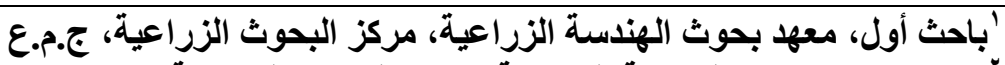

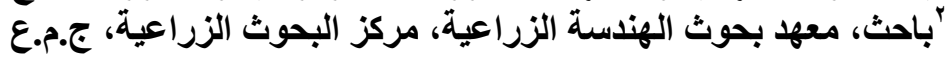




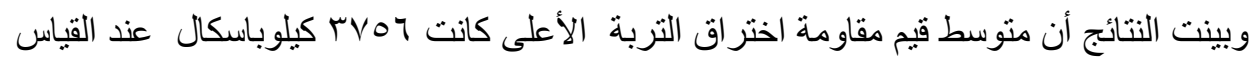

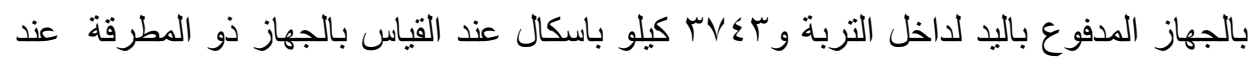

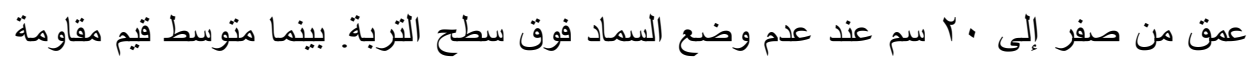

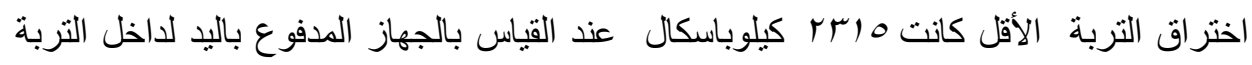

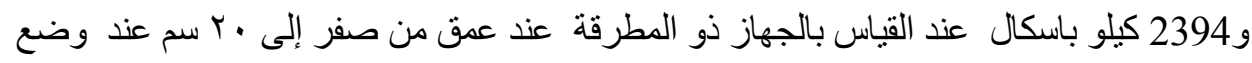

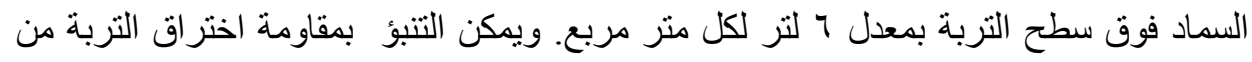

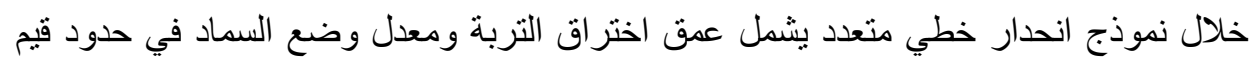

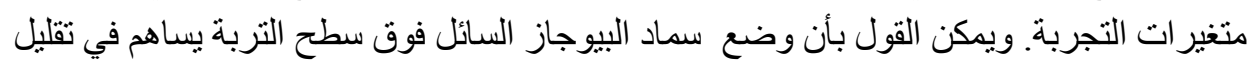

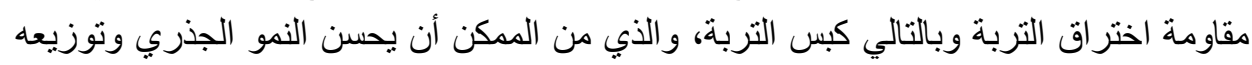

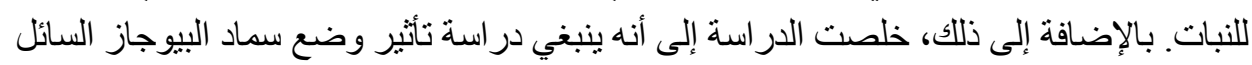
لفترات أطول على سطح التربة على خصائص وقو الف التربة. 